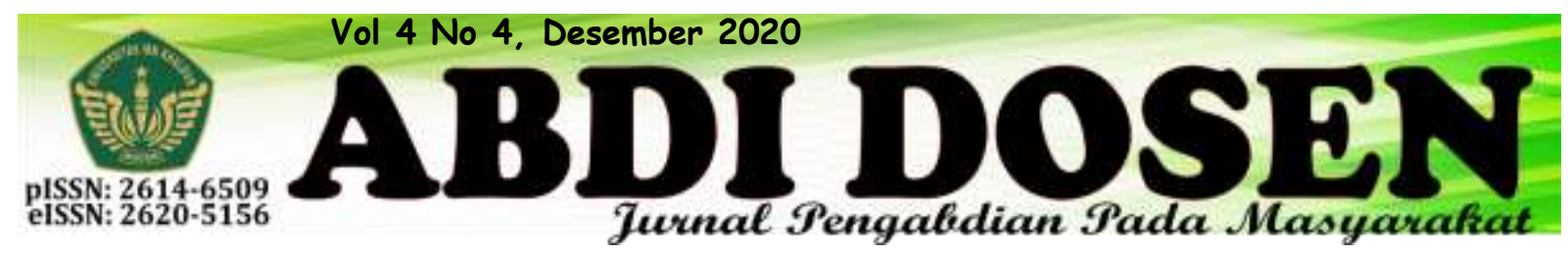

\title{
PEER GROUP SUPPORT DAN PEMANFAATAN HASIL PERTANIAN UNTUK PENCEGAHAN PENULARAN TUBERCULOSIS PARU PADA KELOMPOK BERESIKO
}

\author{
Alfid Tri Afandi ${ }^{1}$, Anisah Ardiana ${ }^{2}$, Ardiyan Dwi Masahid $^{3}$ \\ alfid@unej.ac.id ${ }^{1}$ \\ Fakultas Keperawatan, Universitas Jember ${ }^{12}$, Fakultas Teknologi Pertanian, Universitas Jember ${ }^{3}$
}

\begin{abstract}
Background: Pulmonary tuberculosis is a problem that is relatively high in Indonesia. Pulmonary tuberculosis at the end of 2019 has increased significantly. East Java is one of the provinces with the highest number of pulmonary tuberculosis patients, and Jember Regency is in second place after Surabay a for the number of sufferers. Objective: Increase knowledge of groups at risk of contracting pulmonary tuberculosis with peer group support method and provide information about agricultural materials to increase body immunity not to be susceptible to contracting pulmonary tuberculosis. Methods: Empowering health cadres and giving health education using leaflets and interactive discussions. Results: The implementation of this activity includes the formation of cadres to care for Pulmonary Tuberculosis, mentoring health cadres to conduct health education using a peer group support approach, conducting health education about agricultural materials to increase body immunity. Conclusion: After carrying out these community service activities, it is hoped that the health cadres that have been formed can continue to assist in increasing the knowledge of the surrounding community so that they are not easily infected with pulmonary tuberculosis.
\end{abstract}

\section{Keywords: Peer Group Support, Pumonary Tuberculosis, Agriculture Product, Groups at Risk}

\section{PENDAHULUAN}

Kejadian penyakit Tuberkulosis Paru pada tahun 2019 di Indonesia mengalami peningkatan. Sebaran dari penderita penyakit Tuberkulosis Paru ini sudah hampir merata di seluruh Kawasan di Indonesia termasuk provinsi Jawa Timur. Tren yang terjadi saat ini yaitu jumlah penderita Tuberkulosis Paru tertular dengan bakteri yang sudah resisten terhadap obat (TB-MDR). Indonesia menempati posisi ke 2 di dunia untuk jumlah kasus Tuberkulosis setelah India. Kejadian Tuberkulosis ini meningkat semenjak awal tahun 2000 sampai 2015 di Indonesia (WHO, 2015).

Pemberantasan TB di Indonesia telah dilaksanakan secara Nasional sejak tahun 1969 melalui Program Pemberantasan Tuberkulosis (P2TB) oleh Departemen Kesehatan, dan sejak tahun 1995 lebih diintensifkan dengan cara pengobatan yang mempergunakan strategi Directly Observed Treatment Shortcourse (DOTS) yang direkomendasikan oleh WHO. Namun pada kenyataannya setelah berjalan 9-10 tahun program DOTS, angka keberhasilan pengobatan belum mencapai 
target yang ditetapkan Departemen Kesehatan yaitu dapat menyembuhkan 85\% dari penderita TB paru. Selain itu, WHO telah memperkirakan sejak tahun 2013 bahwa kasus TB Paru dengan MDR (Multi Drug Resistant) di Indonesia meningkat, ini dibuktikan oleh data kejadian kasus baru sebanyak 6.800 penderita. Diperkirakan 2\% dari kasus TB Baru dan $12 \%$ dari kasus TB pengobatan ulang merupakan kasus TB MDR. Data yang didapatkan bahwa lebih dari 55\% pasien TB MDR paru belum terdiagnosis atau mendapatkan pengobatan yang benar (Depkes, 2015).

Provinsi Jawa Timur termasuk provinsi penyumbang terbesar untuk kejadian tuberculosis paru dan Kabupaten Jember yang merupakan lokasi pengabdian ini merupakan kabupaten nomer 2 terbanyak terkait kejadian tuberkulosis di provinsi jawa timur. Seperti diketahui bersama bahwa masalah Tuberkulosis ini merupakan masalah yang urgent dan harus segera diselesaikan penyebarannya. Harapannya dengan meningkatkan pengetahuan dan derajat kesehatan masyarakat akan mencegah terinfeksinya mereka dengan kuman Tuberkulosis. Kementerian Kesehatan menyampaikan bahwa dibutuhkan peran semua sektor dan tatanan masyarakat untuk mengatasi masalah kesehatan seperti Tuberkulosis, DBD, Stunting dll, termasuk melalui peningkatan pemberdayaan perempuan, seperti pemberdayaan kader kesehatan. Antusiasme dan tingginya

\section{MASALAH, TARGET DAN LUARAN}

Berdasarkan hasil wawancara dengan bidan desa di salah satu kecamatan di Kabupaten Jember, didapati bahwa kejadian Tertularnya penyakit Tuberkulosis ini sangat tinggi, dalam 1 motivasi kader kesehatan desa dapat menjadi potensi sumber daya manusia yang efektif untuk penatalaksanaan pencegahan Tuberkulosis di Kabupaten Jember.

$\begin{array}{clr}\text { Untuk } & \text { membantu } & \text { dalam } \\ \text { menyelesaikan } & \text { permasalah } & \text { tentang }\end{array}$ tuberkulosis ini, kami mengusulkan beberapa solusi antara lain:

Pembentukan Kelompok Peduli TB yang berfokus pada pencegahan Tuberkulosis; (2) Pengenalan program untuk pencegahan Tuberkulosis dengan pendekatan peer group support; (3) Simulasi metode peer group support langsung kepada kelompok peduli TB; (4) Pengenalan olahan bahan pertanian yang dapat mencegah $\mathrm{TB}$ dan Meningkatkan Imunitas Tubuh. Memberikan pengenalan tentang bahan pertanian yang dapat diolah menjadi sumber makanan yang bergizi serta dapat meningkatkan imunitas tubuh sehingga dapat meminimalkan resiko penularan Tuberkulosis Paru. Selain itu, dengan adanya dukungan kelompok sebaya (peer group support) diharapkan dapat meningkatkan pengetahuan terhadap pencegahan Tuberkulosis. Dari hasil penelitian Afandi (2016) didapatkan bahwa dengan pendekatan peer group support dapat meningkatkan pengetahuan dan kepatuhan terhadap pasien Tuberkulosis yang menjalani pengobatan. Melalui program ini harapannya dapat mengurangi angka sebaran penderita Tuberkulosis dan meningkatkan derajat kesehatan masyarakat di Kabupaten Jember.

bulan terakhir angka kejadian tertularnya penyakit ini mencapai 5-10 kasus tiap bulannya di beberapa Desa. Penderita baru mayoritas tidak paham dengan penyakit ini dan hanya mengira bahwa terkena sakit 
batuk biasa. Menurut Bidan desa sudah memberikan penyuluhan tentang pencegahan dan deteksi awal tentang penyakit Tuberkulosi/TB ini dibantu dengan Kader Kesehatan Desa, namun melihat jumlah penderita masih banyak dirasa perlu dilakukan evaluasi tentang tehnik penyampaian penyuluhan kesehatan ini.

Informasi dari bidan tersebut mengatakan bahwa program pencegahan TB Nasional dan penyuluhan kesehatan telah dilaksanakan dan berjalan normal. Namun, kondisi sumber daya manusia yang mayoritas Pendidikan rendah kurang bisa memahami tentang persebaran kuman Tuberkulosis dan pentingnya nutrisi untuk menjaga daya tahan tubuh. Berdasarkan data dari BPS Kabupaten Jember (2017) didapatkan bahwa di salah satu desa di Kabupaten Jember sejumlah 986 Rumah Tangga miskin dan ekonomi rendah sehingga dapat juga mempengaruhi tingkat nutrisi yang didapat.

Selain hal tersebut, menurut bidan desa juga disebutkan bahwa kurang tanggapnya masyarakat akan bahaya penyakit Tuberkulosis paru ini juga menjadi perhatian khusus, mereka menganggap bahwa penyakit ini seperti penyakit biasa dan bisa sembuh ketika dengan cukup istirahat. Masyarakat hanya berfokus kepada bagaimana menjaga kesehatan diri sendiri tanpa mempedulikan kesehatan orang lain, ini juga dikatakan bidan desa menjadi masalah yang cukup berbahaya dalam persebaran penyakit Tuberkulosis ini. Rata-rata masyarakat hanya untuk batuk yang beretika susah untuk menerapkan, sehingga kejadian
Tuberkulosis cukup tinggi di Kabupaten Jember

Berdasarkan pemaparan diatas, maka permasalahan yang dihadapi oleh mitra dapat diuraikan sebagai berikut:

1. Kurang optimalnya metode penyuluhan kesehatan tentang pencegahan Tuberkulosis

2. Faktor ekonomi masyarakat yang dapat mempengaruhi masyarakat untuk membeli bahan makanan untuk memenuhi gizi seimbang dan meningkatkan imunitas tubuh

3. Kurangnya pengetahuan dan kesadaran masyarakat bahwa penyakit tuberkulosis bisa dicegah

4. Kurang optimalnya penyebar-luasan informasi tentang pencegahan Tuberkulosis.

Target luaran dari program pengabdian ini diharapakan menghasilkan luaran yang berupa:

1. Terbentuknya kelompok peduli Tuberkulosis Paru untuk mencegah kejadian Penularan Tuberkulosis Paru.

2. Kelompok peduli Tuberkulosis Paru mampu mengaplikasikan peer group support secara optimal

3. Meningkatkan pengetahuan pada kelompok peduli Tuberkulosis Paru dan Kelompok Beresiko Tertular Tuberkulosis Paru

4. Meningkatkan Pengetahuan pada kelompok peduli Tuberkulosis Paru dan Kelompok Beresiko tentang hasil pertanian yang dapat meningkatkan imunitas tubuh sehingga dapat mencegah tertularnya kuman Tuberkulosis Paru. 


\section{METODE PELAKSANAAN}

Berdasarkan hasil dari identifikasi masalah tersebut, maka langkah-langkah dalam penyelesaian masalah tersebut diawali dengan melakukan permohonan ijin kepada masyarakat setempat untuk melakukan beberapa kegiatan. Kemudian setelah mendapat ijin, dilanjutkan dengan membentuk kelompok peduli tuberkulosis paru atas saran dan usul dari pemuka masyarakat setempat. Setelah terbentuk kelompok peduli tuberkulosis dan telah diresmikan, dilanjutkan dengan pembekalan materi pencegahan penularan tuberkulosis paru untuk kelompok peduli tuberkulosis dengan pendekatan peer group support. Langkah selanjutnya kelompok peduli tuberkulosis paru tersebut melakukan penyuluhan kepada kelompok

\section{HASIL PEMBAHASAN}

Pendidikan kesehatan dengan pendekatan peer group support telah dilaksanakan pada kelompok peduli tuberkulosis dan kelompok beresiko tertular tuberkulosis paru. Pelaksanaan dilakukan dengan beberapa tahapan, yang pertama pada tanggal 11 September 2020 dilakukan pembentukan kelompok peduli tuberkulosis paru. Pada saat pembentukan ini disahkan oleh aparatur desa atau tokoh masyarakat desa. Kelompok peduli tuberkulosis paru selanjutnya di singkat menjadi Tim Cepat yang memiliki kepanjangan arti "cegah dan tanggap penanganan Tuberkulosis". Setelah resmi terbentuk dilanjutkan dengan pemberian materi pencegahan Tuberkulosis paru dengan pendekatan peer group support. Sebelum diberikan materi, kelompok peduli tuberkulosis paru diukur terlebih dahulu pengetahuannya tentang Tuberkulosis Paru dan setelah diberi beresiko dengan pendekatan peer group support dengan topik cara mencegah penularan Tuberkulosis Paru. Pada fase terakhir kelompok peduli Tuberkulosis paru dan kelompok beresiko diberikan Pendidikan kesehatan tentang hasil olahan pertanian yang dapat meningkatkan imunitas tubuh sehingga dapat mencegah tertularnya Tuberkulosis Paru.

Metode dalam mengevaluasi keberhasilan program ini yaitu dengan pengukuran pengetahuan dari kelompok peduli tuberkulosis dan kelompok beresiko tertular tuberkulosis. Pengukurannya dilakukan dengan kuesioner pengetahuan tentang Tuberkulosis paru dari penelitian Afandi (2016).

materi diukur kembali pengetahuannya. Hasil dari pengukuran pengetahuan sebelum diberikan materi (pre test) didapatkan skor rata-rata 50 dari total skor 100, setelah diberikan materi didapatkan skor rata-rata 75 dari total skor 100. Dari hasil tersebut menandakan adanya peningkatan pengetahuan dari kelompok peduli tuberkulosis setelah diberikan materi pencegahan penularan tuberkulosis paru dengan pendekatan peer group support. Sesuai dengan penelitian dari Ilkafah (2012) dan Afandi (2016) bahwa Pendidikan kesehatan dengan pendekatan peer group support dapat meningkatkan pengetahuan terhadap penyakit diabetes millitus dan tuberkulosis paru. 


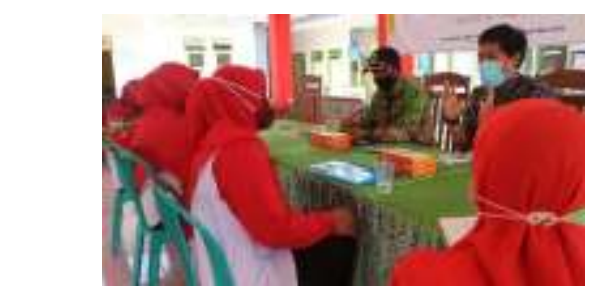

Gambar 1 Pembentukan Kelompok Peduli Tuberkulosis Paru

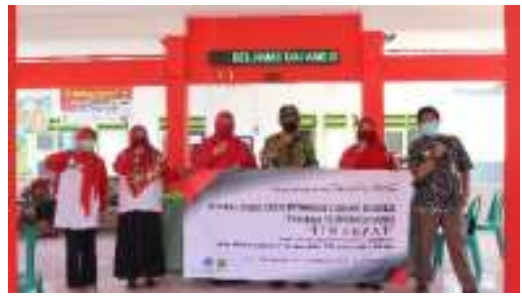

Gambar 2 Tim CEPAT

Setelah kelompok peduli Tuberkulosis Paru terbentuk, maka untuk tahap selanjutnya adalah pemberdayaan kelompok tersebut untuk memberikan Pendidikan kesehatan kepada kelompok beresiko tertular Tuberkulosis Paru. Pada pertemuan selanjutnya dilakukan Pendidikan kesehatan dengan pendekatan peer group support pada kelompok beresiko. Mekanisme kegiatan sama yaitu diukur pengetahuan pre dan postnya. Nilai rata-rata untuk pre test dari kelompok beresiko adalah 37,5 dari total skor 100 dan nilai rata-rata untuk post test 47,7 dari total skor 100. Dari hasil tersebut terjadi peningkatan skor namun tidak terlalu signifikan. Peningkatan pengetahuan pada kelompok beresiko yang tidak terlalu signifikan dapat terjadi karena pengaruh faktor usia, karena kelompok beresiko yang dihadirkan mayoritas kelompok lansia. Menurut penelitian dari Putri (2015) dan Afandi (2016) didapatkan bahwa faktor usia dapat mempengaruhi peningkatan pengetahuan dari penderita Tuberkulosis Paru yang sedang menjalani terapi pengobatan.

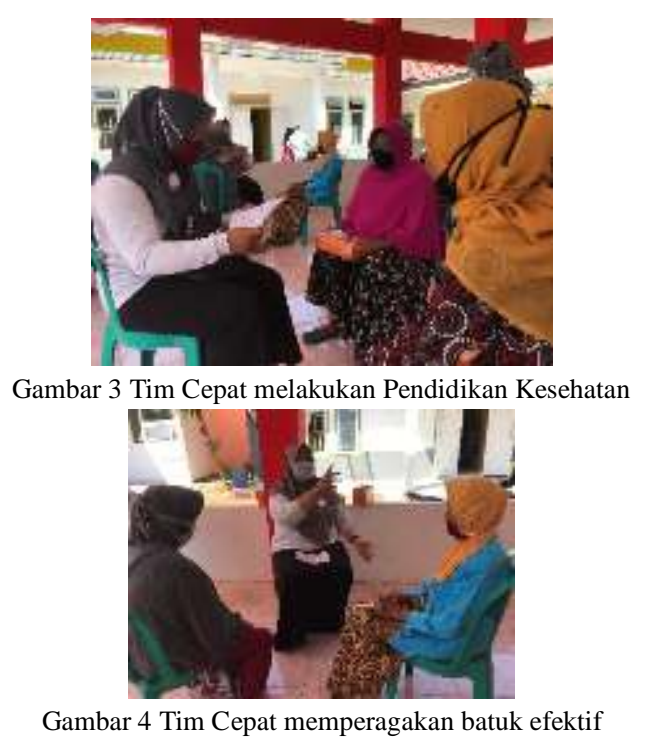

Pada tahap terakhir dari kegiatan ini yaitu dilakukan penyuluhan tentang pengolahan hasil pertanian untuk meningkatkan imunitas tubuh sehingga tidak tertular oleh bakteri tuberkulosis paru. Penyuluhan dilakukan oleh tim dari pengabdi serta mekanismenya adalah ceramah. Sebelum diberikan pemaparan materi, dilakukan pengukuran pengetahuan dari peserta dengan cara diberikan pertanyaan acak sebanyak 5 pertanyaan dan yang terjawab dengan benar hanya 1 . Setelah diberikan materi dilakukan evaluasi dengan pertanyaan yang sama, peserta dapat menjawab ke 5 pertanyaan tersebut dengan tepat. Mekanisme Pendidikan kesehatan dengan metode ceramah dan diskusi secara langsung dapat meningkatkan pengetahuan dari peserta, namun banyak faktor juga yang dapat mempengaruhi proses transfer pengetahuan dari penyuluh dan peserta. Beberapa faktor yang dapat mempengaruhi peningkatan pengetahuan peserta adalah tehnik komunikasi, media dan pendidikan peserta (Utami dkk, 2018; Avista, 2018) 


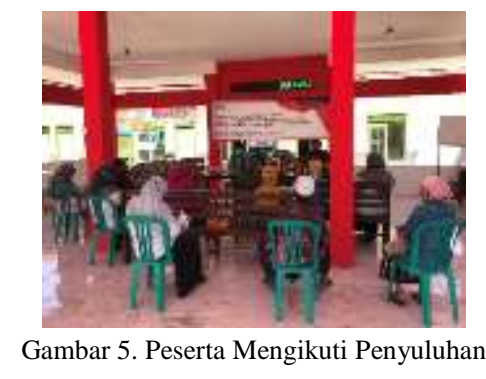

\section{KESIMPULAN DAN SARAN}

Kesimpulan dalam kegiatan yang telah dilakukan ini adalah bahwa ada peningkatan pengetahuan pada kelompok beresiko tertular penyakit Tuberkulosis Paru dengan pendekatan metode kesehatan peer group support serta adanya peningkatan pengetahuan terkait pengolahan bahan petanian yang dapat meningkatkan imunitas tubuh sehingga

\section{DAFTAR PUSTAKA}

Afandi, A.T. 2016. Peer group support effectivity toward the quality of life among pulmonary tuberculosis and chronic disease client : a literature review. NurseLine Journal. ISSN 2541 464X. https://jurnal.unej.ac.id/index.php/NL J/article/view/4901.

Afandi, A.T. 2016. Pengaruh Peer Group Support terhadap Pengetahuan, Sikap, dan Kepatuhan minum obat serta Kualitas Hidup Pasien Tuberkulosis Paru. Thesis. Universitas Airlangga. http://repository.unair.ac.id/45503/.

Avista, N. E. 2018. Pengaruh Pendidikan Kesehatan Metode Ceramah Terhadap Tingkat Pengetahuan Pencegahan Penyakit Glaukoma Pada Klien Beresiko Glaukoma Di Wilayah Kerja Puskesmas Curahnongko Kabupaten Jember.

http://repository.unej.ac.id/handle/123

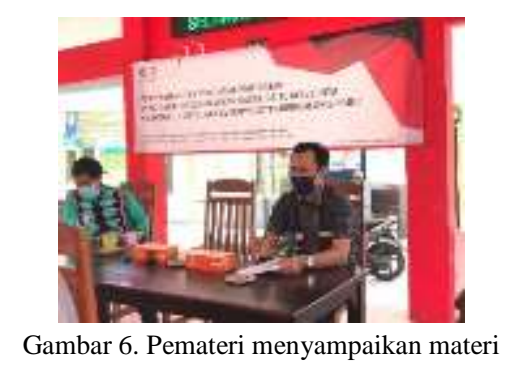

tidak mudah tertular penyakit Tuberkulosis Paru.

Rekomendasi untuk kegiatan pengabdian yang akan datang adalah pemberdayaan kader yang telah terbentuk dalam mengotimalisasi perilaku hidup bersih dan sehat masyarakat sekitar, harapanya bisa lebih mengoptimalkan status kesehatan masyarakat.

\section{$456789 / 88275$}

Dinkes Provinsi Jawa Timur, 2015, Profil Kesehatan Jawa Timur, http://dinkes.jatimprov.go.id/.

Ilkafah. 2012. Pengaruh Peer Group Support Terhadap Self - Efficacy Kontol Gula Darah dan Self Care Activities pada Penderita Diabetes Mellitus Di Puskesmas Mantup Kabupaten Lamongan. Surabaya: Fakultas Keperawatan UNAIR.

Kementerian Kesehatan. 2018. Pusat Data dan Informasi Profil Kesehatan Indonesia 2016. www.kemkes.go.id.

Putri, S.T. 2015. Kualitas Hidup Pada Pasien Tuberkulosis Paru Berdasarkan Aspek Kepatuhan Terhadap Pengobatan di Puskesmas Padasuka Kota Bandung, Jurnal 
Keperawatan Aisyiah Vo.2 No.2 ISSN:2355-6773.

Utami, N.L.A., Ruriani, N., Rahajeng, I.M. 2018. Efektivitas metode peer education dan metode ceramah terhadap tingkat pengetahuan siswa tentang kehamilan remaja

WHO. 2015. Global Tuberculosis Report 2015, http://www.who.int/en/ 